Article

\title{
From Public to Private Standards for Tropical Commodities: A Century of Global Discourse on Land Governance on the Forest Frontier
}

\author{
Derek Byerlee ${ }^{1,2 *}$ and Ximena Rueda ${ }^{2,3}$ \\ 1 Independent Researcher, Washington, DC 20007, USA \\ 2 Center on Food Security and the Environment, Stanford University, Stanford, CA 94305, USA \\ 3 School of Management, Universidad de los Andes, Calle 21 No. 1-20, Bogota, 110311, Colombia; \\ E-Mail: x.rueda@uniandes.edu.co \\ * Author to whom correspondence should be addressed; E-Mail: dbyerlee@gmail.com; \\ Tel.: +1-202-492-2544.
}

Academic Editor: George C. Schoneveld

Received: 11 September 2014 / Accepted: 1 April 2015 / Published: 21 April 2015

\begin{abstract}
Globalization and commodity exports have a long history in affecting land use changes and land rights on the tropical forest frontier. This paper reviews a century of social and environmental discourse around land issues for four commodities grown in the humid tropics - rubber, cocoa, oil palm and bananas. States have exercised sovereign rights over land and forest resources and the outcomes for deforestation and land rights of existing users have been quite varied depending on local institutional contexts and political economy. In the current period of globalization, as land use changes associated with tropical commodities have accelerated, land issues are now at center stage in the global discourse. However, efforts to protect forests and the rights of local communities and indigenous groups continue to be $a d$ hoc and codification of minimum standards and their implementation remains a work in progress. Given a widespread failure of state directed policies and institutions to curb deforestation and protect land rights, the private sector, with the exception of the rubber industry, is emphasizing voluntary standards to certify sustainability of their products. This is an important step but expectations that they will effectively address concerns about the impact of tropical commodities expansion might be too high, given their voluntary nature, demand constraints, and the challenge of including smallholders. It is also doubtful that private standards can more than partially compensate for long standing weaknesses in land governance and institutions on the forest frontier.
\end{abstract}


Keywords: commodities; globalization; land rights; tropical forests; bananas; cocoa; palm oil; rubber

\section{Introduction}

Tropical commodity production has long been the subject of global concerns-from slavery, labor conditions, and fair prices, to deforestation [1-3]. Attention to these concerns is greatest during commodity booms, when private investor interest and land expansion peak, and during commodity busts, when prices, incomes and wages are under pressure. The recent headlines on global "land grabs" and rapid deforestation in the tropics, associated with high commodity prices and growing resource scarcity in the early 21 st century, suggests that concerns about tropical exports continue to be highly relevant $[4,5]$. However, the global discourse on land use has evolved over time, leading to growing recognition of land rights of local and indigenous peoples, and of the local and global ecosystem services provided by forests [6]. In addition, the relative roles of the state and private actors in setting and enforcing social and environmental standards for tropical products has shifted sharply toward the private sector in recent years [7].

This paper reviews the changing discourse related to land use and rights by examining the expansion of four export commodities on the forest frontier over the past century. Our aim is to provide a long-term perspective of how global standards relating to land use and land rights have evolved as a device to better understand the current state of land and forest governance, the shift to private standards, and the prospects that such standards will improve social and environmental outcomes from expansion of tropical commodities. We focus on governance of land use changes in the lowland humid tropics (areas with at least 270 days growing season and under 600 meters above sea level) over the past century. Our approach is to examine the record of the most important export crops that have driven land-use change in the past and that continue to be important today-cocoa (mainly in Africa), rubber and oil palm (mainly in Asia), and bananas (mainly in Latin America). In each case, there was an initial period of rapid growth during what is often termed the first period of globalization from the last half of the 19th century to around 1930 [8]. With the onset of the economic depression, growing protection and World War II, growth was slower in the middle part of the 20th century, with sporadic renewed bursts of activity [8]. Finally, the current period of globalization from around 1990 has been associated with rapid expansion of land use for tropical commodities, including new entrants - notably soybeans.

We give particular attention to how land rights and environmental services were treated on the forest frontier in contemporary policy and market contexts during these episodic expansions. A major theme is to understand the relative roles of state and private actors, both local and global, in defining and enforcing policies and institutions related to land use changes and rights.

We begin by outlining a simple framework for the review that highlights important stakeholder groups, institutions, and commodity characteristics that influence the impacts of land use changes. This is followed by a brief overview of the evolution of each of the four commodities over the past century. The next section then uses the commodity reviews to analyze changes in governance of land resources on the forest frontier at national and global levels, noting the general failure of state-led efforts to 
sustainably govern land use on the frontier and the rise of private standards that attempt to fill gaps in governance of land resources. We conclude by noting the need to exploit the complementarity of public and private standards if land governance is to be improved on the forest frontier.

\section{Framework for the Review}

Many factors influence land use changes and rights, but increasing globalization and trade in agricultural commodities is now generally recognized as a key driver of such changes both historically and today $[9,10]$. Historically, the state has been the major regulator of land use changes, either through its "ownership" and allocation of land, or through a wide range of policies designed to influence the behavior of private actors with respect to land use [7,11].

Our framework is built around the core elements of policies and institutions that set and enforce standards for sustainability outcomes from land use changes, in both their social (e.g., land rights and agrarian structures) and environmental (e.g., deforestation) dimensions (Figure 1). These are in turn governed by a range of actors from the state, private sector, civil society, local communities, and consumers, from local to global, and by attributes of the commodities themselves, such as processing needs and their relative uses in food, feed and industry (Figure 1). The sustainability outcomes of policies and institutions depend on land use changes, especially conversion of natural vegetation to cropland, impacts on land rights, and the resulting agrarian structure, in particular, the relative roles of large plantations and smallholders in commodity production.

Actors

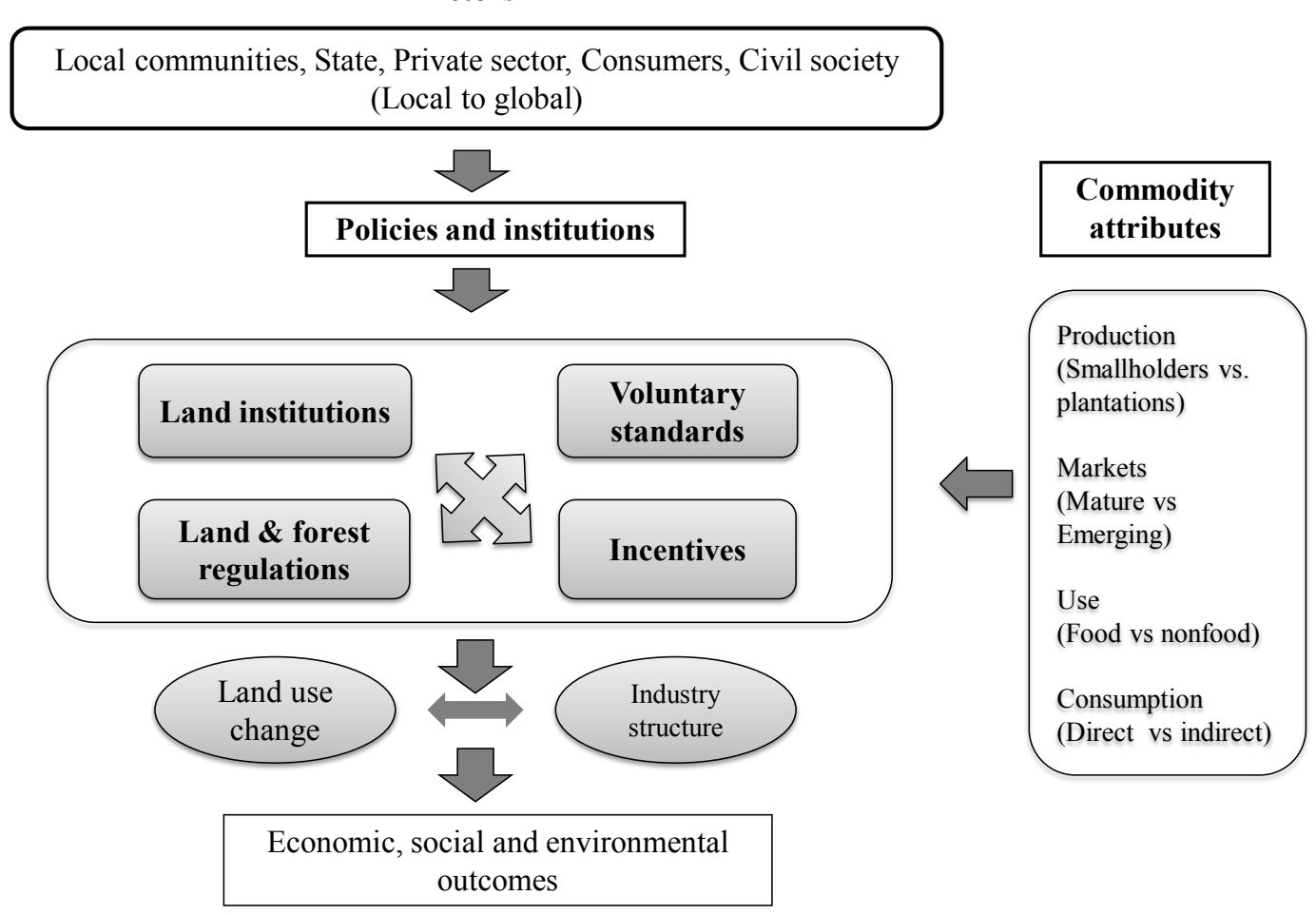

Figure 1. Simplified framework for analyzing outcomes for land use and land rights.

Four core elements make up the policy and institutional context in which land use change takes place. The first and most obvious are land institutions, most importantly the property rights governing 
land and forest resources. These rights may range from private property rights governed by statutory legal systems to customary rights governed by local communities, to state ownership and control. Another important element is the use of incentive schemes, offered through state policies such as cheap land concessions or tax incentives to investors, or on the other side, payments to communities to conserve natural areas and their environmental services. A third element relates to "command and control" systems that regulate land use decisions [7]. Finally, private decisions are also responsive, through a range of voluntary standards, to the socially constructed expectation on the behavior of companies, smallholder farmers and other actors in the value chain. We employ here a broad definition of standards that include socially accepted values, norms, codes, practices or discourses to represent legitimate stakeholders' value systems at a given point in time with respect to local land rights and environmental services provided by forests. These standards may be codified into formal principles and criteria that private actors in the value chain use to voluntarily certify that their produce conforms to their own codes of conduct, satisfy their investors, and meet the expectations of consumers of tropical products.

The institutional arrangements and land governance prevailing at different points in time are the result of the interactions among a range of global and local actors. These actors include multinational companies, consumers, civil society and governments (historically including the metropolitan government of colonial powers). Given our focus on global commodities, we pay particular attention to how global actors influence the discourse on land use and rights.

Finally, we hypothesize that the characteristics of the commodity itself (i.e., the cultivation practices, its processing, its markets and mode of consumption) play a key role in determining the social and environmental outcomes and standards. At the production level, high initial capital requirements, perishability and economies of scale in processing are likely to favor vertically integrated plantations over smallholder production, creating large-scale land use changes, but also the opportunity for establishing comprehensive codes of conduct that a single company can implement. Other commodities may fit easily into smallholder agro-forestry systems that minimize land use changes and impacts on biodiversity. On the retail end, richer and more educated consumers with greater awareness and concerns for global ecosystem services and issues of global justice are more likely to pay for social and environmental standards embodied in commodity production, favoring higher standards for commodities that are largely consumed in high-income countries. Sustainability commitments and premiums are likely to vary considerably depending on whether a commodity is directly consumed, is an ingredient in a processed product, or is used as an industrial input.

This framework can be applied to a wide range of sustainability concerns relating commodity production at different points in time. For the purpose of this paper, we focus on two of these dynamics - how companies and states considered indigenous land rights and the welfare of local communities in their decisions to expand commodity production, and the value (if any) placed on ecological services provided by forests in the process of conversion to commodity production.

\section{Results from the Case Studies}

The four commodities we have selected (rubber, cocoa, palm oil and bananas) have historically been among the main export commodities causing land use changes in the humid tropics. Of the other 
10 top commodity exports (in terms of today's value) that largely originate from the tropics and subtropics, sugar and cotton are now mostly exported from the sub-tropics, while coffee and tea are produced in the mid and higher altitude tropics and have seen very little land use change in the past 50 years [12]. Soybeans and cashews are quite recent export developments without a historical context, and only a small percent of soybean exports are from the humid tropics (about 7\% of Brazilian soybeans are from the Amazon biome) [13]. Beef cattle are undoubtedly the major source of land use change in the humid tropics of Latin America, but demand is being driven more by domestic than global markets [14].

A detailed discussion of land use changes and land rights for each commodity is provided in Supplementary Information (SI). Over the past century, rubber, cocoa, palm oil and bananas underwent major intercontinental shifts in the loci of production from their center of origin to new centers of export dominance (Table 1). Cocoa was already a well-established crop in 1900 in its native tropical Americas, but expanded rapidly in West Africa from around 1900, and smallholders from that region have been the dominant exporters since then. Rubber was harvested wild from Africa and Latin America until after 1900 when cultivation took off in Southeast Asia. Oil palm was harvested by smallholders in West Africa for export from wild or semi-wild trees up to 1900 and only with full domestication in the early 1900s did it produce extensive land use changes with its successful introduction by large plantation companies to Central Africa and Southeast Asia in 1910-1920. Since 1990, it has become by far the dominant tree crop causing tropical land use changes, mostly in Southeast Asia (Figure 2). Bananas were traditionally cultivated in Asia but they developed into a mass export commodity from the early 1900s when countries of Central America and the Andean region became major global exporters, based on a plantation mode of production. Since 1961, when statistics are available, all four crops have expanded steadily, with oil palm area surging since 1990 (Figure 2).

Table 1. Origin and shifts in export production of four tropical commodities in the 20th century.

\begin{tabular}{|c|c|c|c|c|}
\hline Commodity & Rubber & Cocoa & Oil Palm & Bananas \\
\hline Scientific name & Hevea brasiliensis & Theobroma cacao & Elaeis guineensis & Musa acuminate \\
\hline Center of origin & South America & Meso-America & $\begin{array}{c}\text { West \& Central } \\
\text { Africa }\end{array}$ & Southeast Asia \\
\hline Major use & Industrial & Direct for food & $\begin{array}{c}\text { Food ingredient } \\
\text { and industrial use }\end{array}$ & Direct for food \\
\hline First stage processing & Simple & Simple & $\begin{array}{l}\text { Large-scale quickly } \\
\text { after harvest }\end{array}$ & $\begin{array}{c}\text { Large-scale } \\
\text { shipping quickly } \\
\text { after harvest }\end{array}$ \\
\hline $\begin{array}{l}\text { Dominant exporting } \\
\text { region, } 1900\end{array}$ & $\begin{array}{l}\text { South America }{ }^{a} \\
\text { (wild harvests) }\end{array}$ & Americas & $\begin{array}{l}\text { West Africa } \\
\text { (wild harvests) }\end{array}$ & Negligible trade \\
\hline $\begin{array}{l}\text { Dominant exporting } \\
\text { region, } 2010\end{array}$ & Southeast Asia & West Africa & Southeast Asia & Americas \\
\hline $\begin{array}{l}\text { Dominant importer, } \\
1900\end{array}$ & $\begin{array}{l}\text { USA, Western } \\
\text { Europe }\end{array}$ & $\begin{array}{c}\text { Western Europe, } \\
\text { USA }\end{array}$ & Western Europe & Negligible trade \\
\hline $\begin{array}{l}\text { \% exports to high } \\
\text { income countries } \\
-1961 \\
-2010 \\
\end{array}$ & $\begin{array}{l}64 \\
47 \\
\end{array}$ & $\begin{array}{l}88 \\
74 \\
\end{array}$ & $\begin{array}{l}81 \\
24 \\
\end{array}$ & $\begin{array}{l}91 \\
75 \\
\end{array}$ \\
\hline
\end{tabular}

${ }^{\text {a }}$ Wild rubber from other species was also exported from Africa; Source: [12] and Authors. 
Although all four crops saw rapid expansion in the first part of the 20th century, there are important differences in the way that they were produced and the markets they served. Once the crop moved from wild or semi-wild harvesting to cultivation, all started cultivation on medium and large plantations. However, over time, they have moved to predominantly smallholder production systems including agroforestry systems in the case of cocoa and rubber, or mixed small, medium and large holder systems (as in the case of bananas and palm oil). All were originally produced for markets in Europe and North America but that has shifted over time, especially for palm oil. The degree to which they were consumed directly as a food was highest for bananas while rubber was destined for industrial uses.

Our review of four commodities across three major geographies (see SI) demonstrated a number of common elements as well as important differences across space and time in outcomes with respect to land use and land rights summarized in Table 2.

The impact of commodity expansion on tropical deforestation and land rights has depended greatly on the ways that land and labor were accessed. In the early years of the 20th century, when the plantation mode of production prevailed, large land concessions by governments were the favored approach to providing incentives to plantation investors. The path of least resistance was for the state to take over forestland in low population density areas and allocate it through land concessions for the development of tropical commodities. A low value was placed on forest resources at the time and by focusing on low-density population areas, land conflicts were reduced (although not avoided). This use of land concessions mediated by the state to attract investors has continued to be the basic model in use today in much of tropical Africa and Southeast Asia (SI).

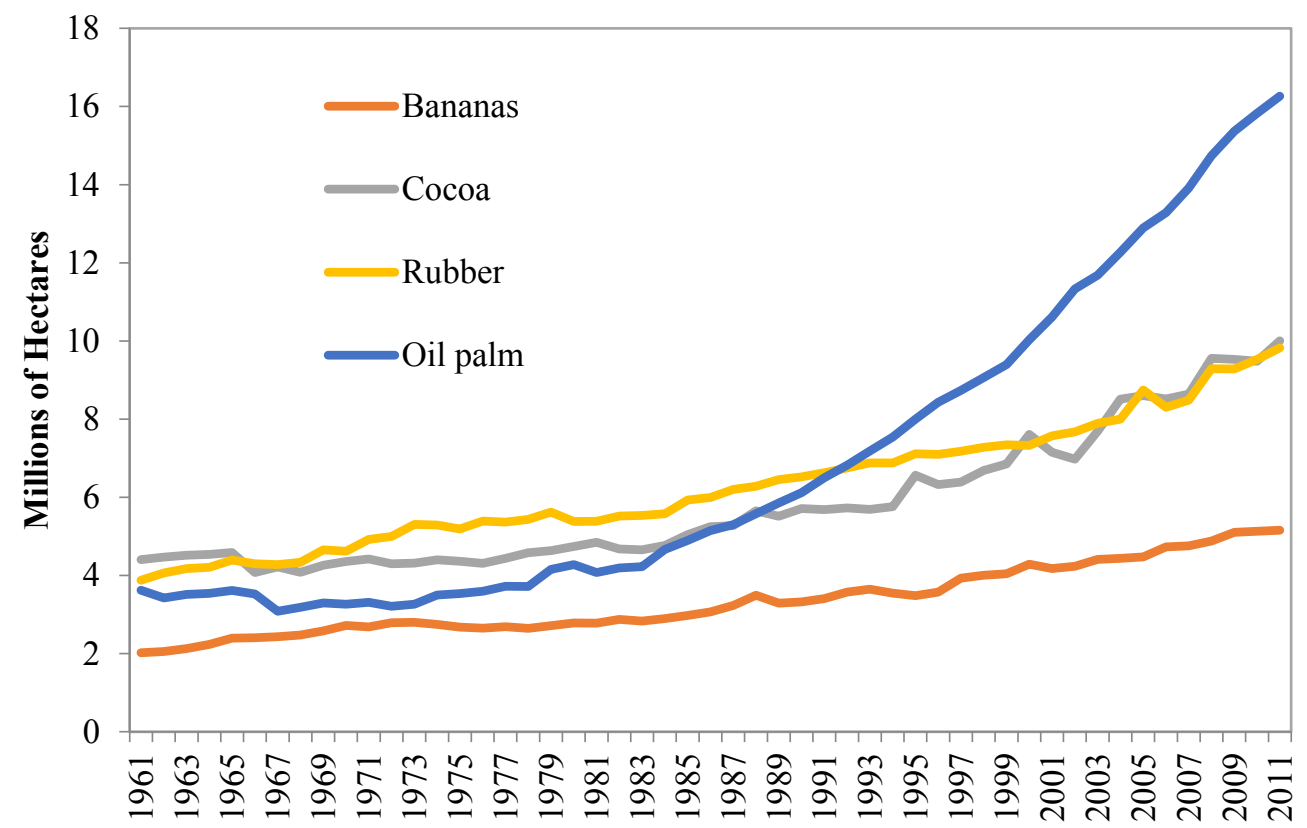

Figure 2. Global area of bananas, cocoa, rubber and oil palm 1961-2011. Note: For cocoa, oil palm, and rubber, the large majority of area expansion is for exports. For bananas, an important share is for subsistence consumption or domestic markets; Source: [12]. 
Table 2. Summary of major outcomes for land use and land rights from expansion of four tropical commodities in the early and late 20th century.

\begin{tabular}{|c|c|c|c|c|}
\hline & Rubber & Cocoa & Oil Palm & Bananas \\
\hline \multicolumn{5}{|c|}{ 1900-1939 } \\
\hline $\begin{array}{l}\text { Land use } \\
\text { change }\end{array}$ & $\begin{array}{l}\text { Land concessions in } \\
\text { low density forested } \\
\text { areas of SE Asia but not } \\
\text { the major cause of } \\
\text { deforestation. } \\
\text { Rapid incorporation of } \\
\text { rubber into smallholder } \\
\text { agroforestry systems }\end{array}$ & $\begin{array}{l}\text { Clearing of forests by } \\
\text { cocoa haciendas in } \\
\text { land extensive systems } \\
\text { of coastal Ecuador. } \\
\text { Clearing of forests in } \\
\text { land extensive systems } \\
\text { by smallholders } \\
\text { in Ghana }\end{array}$ & $\begin{array}{l}\text { Land concessions in } \\
\text { low density forested } \\
\text { areas of Congo DRC } \\
\text { and SE Asia but not } \\
\text { a major cause of } \\
\text { deforestation }\end{array}$ & $\begin{array}{l}\text { Locally important } \\
\text { source of deforestation } \\
\text { by multinational } \\
\text { companies in land } \\
\text { extensive systems in } \\
\text { coastal Central America } \\
\text { and national companies } \\
\text { in coastal Colombia } \\
\text { and Ecuador. }\end{array}$ \\
\hline $\begin{array}{l}\text { Land } \\
\text { rights }\end{array}$ & $\begin{array}{l}\text { Tension between } \\
\text { shifting cultivators and } \\
\text { plantations based on } \\
\text { concessions. Serious } \\
\text { conflicts in Vietnam } \\
\text { and Cambodia. } \\
\text { Elsewhere in Asia, } \\
\text { expansion mostly } \\
\text { through in situ } \\
\text { smallholders }\end{array}$ & $\begin{array}{l}\text { Few conflicts. In } \\
\text { Ecuador haciendas had } \\
\text { formal property rights. } \\
\text { In Ghana, immigrants } \\
\text { accessed land through } \\
\text { local chiefs in return } \\
\text { for provision of labor }\end{array}$ & $\begin{array}{l}\text { Conflicts in Congo } \\
\text { DRC over very large } \\
\text { concession of } \\
750,000 \text { ha to Lever } \\
\text { Brothers. }\end{array}$ & $\begin{array}{l}\text { Serious conflicts over } \\
\text { very large concessions } \\
\text { and land acquisition by } \\
\text { United Fruit amounting } \\
\text { to } 1.4 \mathrm{Mha}\end{array}$ \\
\hline \multicolumn{5}{|c|}{ 1980-2010 } \\
\hline $\begin{array}{l}\text { Land use } \\
\text { change }\end{array}$ & $\begin{array}{l}\text { Both smallholder and } \\
\text { large concessions } \\
\text { expand rapidly in } \\
\text { Cambodia, Laos and } \\
\text { Myanmar at the } \\
\text { expense of an estimated } \\
0.5 \mathrm{M} \text { ha forests }\end{array}$ & $\begin{array}{l}\text { Serious local } \\
\text { deforestation from } \\
\text { smallholder cocoa } \\
\text { as production shifts } \\
\text { to Cote d'Ivoire } \\
\text { and Indonesia }\end{array}$ & $\begin{array}{l}\text { Dramatic expansion } \\
\text { of oil palm by over } \\
10 \text { Mha, mainly in } \\
\text { Malaysia and } \\
\text { Indonesia. One of } \\
\text { major causes of } \\
\text { deforestation with } \\
\text { one third of planted } \\
\text { area by clearing } \\
\text { of forests }\end{array}$ & $\begin{array}{l}\text { Area of export bananas } \\
\text { stagnant or declining } \\
\text { due to improve yields } \\
\text { and transition from } \\
\text { shifting to permanent } \\
\text { plantations. }\end{array}$ \\
\hline $\begin{array}{l}\text { Land } \\
\text { rights }\end{array}$ & $\begin{array}{l}\text { Major conflicts in } \\
\text { Cambodia, Laos and } \\
\text { Myanmar. }\end{array}$ & $\begin{array}{l}\text { Major conflict and } \\
\text { civil war between } \\
\text { immigrants and } \\
\text { indigenous groups } \\
\text { in Cote d'Ivoire. } \\
\text { Conflicts also with } \\
\text { immigrant smallholder } \\
\text { expansion in Indonesia }\end{array}$ & $\begin{array}{l}\text { Major conflicts in } \\
\text { Indonesia and } \\
\text { Eastern Malaysia as } \\
\text { concessions expand } \\
\text { at expense of local } \\
\text { communities. Also } \\
\text { conflicts with } \\
\text { immigrant farmers. }\end{array}$ & $\begin{array}{l}\text { Few conflicts as } \\
\text { companies reduce land } \\
\text { area under own } \\
\text { plantations, intensify } \\
\text { production on existing } \\
\text { area and shift to } \\
\text { contract farming model }\end{array}$ \\
\hline
\end{tabular}

Source: SI.

The expansion of rubber, cocoa, oil palm and bananas over the 20th century often occurred at the expense of tropical forests and each of the commodities reviewed were at various times major drivers 
of land use change in specific locations. The first wave of globalization brought about the transformation of parts of the Atlantic and Pacific coastal forests of tropical Latin America (cocoa and bananas) [15,16], as well portions of the Guinean Forest in West Africa (cocoa) [17] and of northern Sumatra and parts of Peninsular Malaysia (rubber, oil palm) [18]. However, annual rates of deforestation in the tropics accelerated only slightly to 1.0 Mha during the first period of globalization, 1850-1919, relative to 1750-1850 [9]. Tropical commodities were usually secondary to population growth, food production and timber extraction in driving deforestation at the time [9,19]. No detailed data are available on land use changes at the time, but based on export data and yields, we estimate that no more than 0.1 Mha of tropical forests were lost per year due to expansion of the four commodities reviewed from 1900-1930.

By contrast, the current wave of globalization is on a much larger scale with annual rates of tropical deforestation from 1990-2005 have averaged around 10 Mha [9]. Expansion of commodity production for global markets is now generally regarded as a major driver of tropical deforestation except in Africa [19-21]. Of the four commodities reviewed, by far the most important has been the expansion of oil palm in Southeast Asia by about $11 \mathrm{M}$ ha since 1980 [12] with about one third of this on previously forested land [22]. Rubber, described as a "juggernaut" for deforestation in Southeast Asia [23], and cocoa, described as "consumption of forests" [24,25], have also been important causes of deforestation in the modern period.

In addition, extensive production systems were practiced to maintain soil fertility and control diseases and pests, at least for bananas in the early stages and for cocoa until today. Less than $25 \%$ of land concessions for bananas were actually planted at any given time [2,15]. Clough [24] estimates that the forestland cleared for cocoa from 1960-2010 was about 6.4 Mha, or more than twice the increase in area under cocoa cultivation.

The record of the rise of tropical commodity exports in terms of land rights of local communities is highly varied across regions. In British West Africa, colonial authorities gave precedence to local land rights over land concession for plantations for oil palm and rubber (See SI). By contrast, for bananas in Central America in the early years and oil palm in Indonesia in recent years, land conflicts were inevitable, given the very large areas allocated to plantation companies. In general, conflicts were less frequent in the first period of globalization, when investments generally took place in sparsely populated forested areas although there were important exceptions such as rubber in Vietnam (See SI). Conflicts increased with population growth and the plantations themselves were often the magnets for in-migration due to their high labor demands as well as the provision of infrastructure that opened the frontier. The focus on low density forested areas to develop plantations required facilitating access to labor that in all cases was provided by distant migrants from poorer and densely populated areas within the country or in many cases from abroad. Given the need to recruit labor from long distances, and feed and house them, labor rights and conditions rather than land rights have historically dominated the discourse on tropical commodities (See SI).

The global discourse on tropical commodities with respect to land rights was also in part muted by the rise of smallholder production systems for export commodities over the past century [17,26]. Where smallholders incorporated export crops into existing farming systems, land conflicts and forest losses were reduced. This was particularly the case for rubber in Southeast Asia and cocoa in West Africa (See SI). Indeed, smallholders have often used these tree crops to secure their land rights, in 
accordance with prevailing customary tenure systems, and in part to protect land from outside encroachment by plantation companies or by extension of government forest reserves [27]. However, in areas of low population density, smallholder systems have often been based on migrants as seen for cocoa in West Africa and oil palm in Indonesia. When land was relatively abundant, effective land transactions systems emerged between local communities and migrants; but in the absence of formal land tenure systems such informal transactions risked conflicts in the long run with growing land scarcity.

The relative efficiency and advantages of plantations versus smallholders has been a recurring debate in the history of commodity production. In the early $1900 \mathrm{~s}$, the prevailing wisdom was that plantations linked to global capital and product markets were the most efficient production system [28]. However, the rapid and spontaneous expansion of smallholder cocoa in West Africa, followed by growth of smallholder exports of rubber in Asia refuted the myths of smallholder backwardness and antipathy to market forces and the inherent efficiency of smallholders was recognized in colonial texts by the 1930s [29,30]. Large plantations owed much of their survival to biased policies and subsidies, such as cheap land concessions carved out of the forest reserve [26]. All four commodities have moved decisively toward smallholder systems over the past century (Table 3). Even so and continuing until today, the potential of smallholders has been consistently underestimated by governments and private capital alike.

Table 3. Percent cultivated area of crops for exports under large plantations in a region at three different periods in time: 1905, $1930 \& 2010$ (Numbers in bold indicate the dominant exporting region at the time).

\begin{tabular}{|c|c|c|c|c|c|c|c|c|c|c|}
\hline \multirow[t]{2}{*}{ Region } & \multicolumn{3}{|c|}{ Rubber } & \multicolumn{3}{|c|}{ Cocoa } & \multicolumn{2}{|l|}{ Oil palm $^{\text {a }}$} & \multicolumn{2}{|c|}{ Bananas $^{a}$} \\
\hline & 1905 & 1930 & 2010 & 1905 & 1930 & 2010 & 1930 & 2010 & 1930 & 2010 \\
\hline Africa & & & & $>95$ & 78 & $<10$ & $10-15^{b}$ & 8 & & \\
\hline Americas & & & & $>95$ & $>95$ & & & & 100 & $\approx 35^{\mathrm{c}}$ \\
\hline Asia & 100 & 55 & 17 & & & $<10$ & 100 & $\approx 60$ & & \\
\hline
\end{tabular}

\section{Discussion}

Figure 1 provides a useful framework for discussion of the main drivers of social and environmental outcomes - land institutions, command and control policies, incentives, and voluntary standards_-before turning to the role of global actors and commodity characteristics.

\subsection{The Role of Land Institutions}

Ownership and use of forest and farmland resources have been, for the most part, left to the jurisdiction of national governments, whether independent or colonial. Most European-based legal systems recognized the rights of those cultivating land in permanent agricultural systems and these rights were generally respected by the colonial powers, except in the temperate areas where immigrants 
from Europe settled [32]. To be sure, there was an element of self-interest in this since taxation of permanently cultivated land was a major source of state revenues [33].

In contrast, in frontier areas where tropical commodities were largely produced and shifting cultivation was practiced, customary land rights were poorly recognized. Indeed, the major legal text for the British colonies on forest law in 1893 explicitly recommended against recognizing rights for shifting cultivation:

"Shifting cultivation could not give rise to any permanent title...quite unlike the case of regular land revenue where the government recognizes the person as the proprietor." Baden-Powell p. 338 [34].

Even when statutory laws recognized customary tenure in areas of shifting cultivation, they rarely considered the rights of existing forest users for timber and non-timber forest products and services such as grazing, and thus frequent conflicts arose with local communities that traditionally enjoyed the rights to the forest commons within their territorial jurisdictions [35]. There were important exceptions such as in Ghana where the legal rights of communities to forest resources was successfully contested by strong organizations of indigenous peoples (See SI) or in other cases, where rights to use of forest resources, if not ownership, were recognized, such as in colonial Sarawak [36].

Land laws and property rights today reflect these historical roots with customary rights to land in extensive systems taking a backseat to statutory rights that favor companies seeking access to land [4,37]. Even where customary law is fully recognized, progress in demarking boundaries of communities and formally registering them has been extremely slow [4].

With growing land scarcity and continuing high commodity prices, the recognition and registration of rights of local farmers or communities has become imperative for both sustainable agricultural investments and smallholder development. Even in areas where exports are smallholder-based, land conflicts are common. Commodity booms lead to greater competition for land on the frontier including from in-migrants. In situations of tenure insecurity and unequal power relations, smallholders too may become "land grabbers", sometimes with serious land conflicts [38], as seen in the case of cocoa in Côte d'Ivoire and smallholder oil palm in Indonesia [39,40]. Further, with high commodity prices since 2007, there has been a resurgence of investments in large plantations in those countries with the weakest land and forest governance, abetted by policies that provide cheap land through concessions [26,41].

Thailand, the world's leading producer of a number of tropical commodities (rubber, oil palm, sugarcane), has long given priority to land tenure security even in areas demarcated as state forests, and has managed to increase world market share almost entirely through smallholder systems [26,42]. However, Thailand is an exception and ill-defined and insecure rights of farmers on the forest frontier remain the norm in much of the tropical world.

\subsection{Incentives through Cheap Land Concessions}

The major incentive provided by states to the establishment of tropical commodities was the provision of cheap "state-owned" land through large land concessions to plantation companies. States generally classified tropical forests as "wastelands" (called baldios in Latin America, from the Arab balyd, meaning without value) [43]. Until quite recently, the economic development ethos was perceived as turning "unproductive" forests into productive activities, such as commodity exports, 
thereby contributing to "civilization and progress" [9]. That gave the state the authority to expropriate and grant lands that it considered idle for timber extraction and for development of agricultural exports. As late as 1972, Little and Tipping [44], the leading experts on appraisal of investment projects, provided the following guidance on evaluating investment in oil palm in Malaysia:

"The social cost of land is given by its productivity in the best alternative use, and the existence of large areas of virgin jungle in Malaysia implies a zero opportunity cost."

Over time with growing demand for land for tropical commodities, state-led land concession policies resulted in serious deforestation and infringement on the rights of local land and forest users. All four commodities provide examples of these processes at work, especially the very large land concessions for bananas in Central America and for oil palm in the Congo and in Indonesia (See SI). Even where rules on land concession recognized the value of forest resources and local land rights, their implementation was often flawed due in part to lack of resources for prior surveys and registration of village land, and in part due to pressures by companies on the state to look the other way in enforcing regulations $[45,46]$. In the case of bananas, independent governments in the small countries of Central America supported by local elites were often unwilling or unable to confront companies backed by the US government, especially before WWII [47]. Commodity booms in particular encouraged rent seeking behavior as well as speculation on land resources. These problems continue until today as exemplified with the recent oil palm and rubber booms in Southeast Asia [26].

Without international standards, states were also often encouraged into a "race to the bottom" to attract investors regardless of indigenous rights. The movement of oil palm from British West Africa to the Congo, and later from Peninsular Malaysia to Indonesia reflect these trends (SI). In British West Africa, land concession models were not used to encourage plantation development largely out of concern by the colonial governments for local land rights. After 1950, coinciding with independence for many states, nationalistic pressures that re-asserted national sovereignty over land, and the high visibility of very large land holdings of foreign-owned plantations raised the transactions costs to companies of accessing and holding large land areas These costs have encouraged companies to devolve to smallholders and led to the emergence of alternative institutional arrangements such as contract farming of bananas with small and medium growers in Latin America $[48,49]$ and nucleus-outgrower schemes for oil palm in Indonesia [50].

\subsection{Command and Control Policies}

Regulation and protection of forestland arose in part from widespread belief by colonial officials and independent governments alike that shifting cultivation (the normal practice in forested areas) was a wasteful and unsustainable approach to farming. Colonial officials were obsessed with the perceived damage of shifting cultivation. As late as 1940, Troup [51] wrote in the main text for colonial foresters in the British Empire:

"From various points of view shifting cultivation may be regarded as an extremely harmful practice"

The perceived harmful effect of shifting cultivation was the official motivation for forming state-owned and managed forest reserves. As stated by colonial forest official in Malaya (as cited in [52], p. 761): 
"In any country where shifting cultivation is the normal form of agriculture practiced by the native, the formation of [forest] reserves....before irreparable damage is done to the primeval forests, must be the first consideration."

To be fair, there was also growing understanding of the local environmental values of conserving forests to control soil erosion, maintain hydrology, and regulate local climate $[9,17]$. By the late 19th century, the scientific school of forestry based on the German model had become well established in the tropics as a rationale for state intervention to sustainably manage timber yields and to promote soil and water retention and regulate climate at the local level $[17,53]$. The main vehicle to protect forests was through the establishment of forest reserves under state management, usually with the exclusion of traditional users [9].

Efforts at conservation, although often well-meaning and perceived as acting in the interest of the public good for local communities and national development [18], were widely contested and often led to conflicts [35]. Within colonial governments, there was considerable disagreement of the forestry departments with departments charged with promoting economic progress, especially agricultural departments that emphasized the development of commodity exports [53]. Further, the forest reserve policies were frequently not effective in conservation given the state's lack of capacity to enforce regulations or the pressure to convert land to commodity production in times of high prices [35]. Nonetheless, the state was sometimes effective in protecting forest resources with good examples in colonial times in Nigeria [54] and recently in Costa Rica [55]. There is also evidence that state protected forests have experienced slower rates of deforestation in recent years [56].

\subsection{Voluntary Standards}

The limited success of institutions, incentives and command-and-control mechanisms to halt deforestation and protect land rights has produced a shift in the 21 st century to voluntary mechanisms implemented by the private sector to promote sustainable land use and forest management (SI) [7]. These build on interesting historical examples of multinational companies enforcing private standards to fill gaps in state policies. The boycott by British chocolate firms of imports from Portuguese African colonies in the early 1900s is a good example of early corporate social responsibility, in part reflecting the values of company owners and in part to head off a consumer backlash [57]. Likewise, United Plantations established in the 1920s has been a long-term leader in setting standards for oil palm in Malaysia [58]. In both cases, the focus of voluntary standards was on labor rights and conditions.

There are now a suite of mechanisms led by the private sector: strict bans and moratoria imposed by buyers, third-party certification of sustainable practices by producers (for both forests products and agricultural commodities), multi-stakeholder industry-led agreements for certifying best practices, and company-defined codes of conduct. All try, with different levels of effort, to promote sustainable land uses and the conservation of natural ecosystems. Of the commodities reviewed here, the cocoa and banana industry are using third party certification and generic standards that may include some clauses specific to the industry. In the cocoa industry, UTZ is the leading certification system, while in bananas it is the Rainforest Alliance code of conduct that prevails. In oil palm, the Roundtable for Sustainable Palm Oil (RSPO) now made up of nearly 1000 members with diverse roles or interests in 
the industry has developed standards through broad multi-stakeholder processes that are specific to oil palm. In the case of rubber, efforts to introduce standards are still in their infancy [59].

The initial motivation for these standards has varied considerably. Only in the case of oil palm's RSPO has the primary motivation been to slow deforestation and reduce land conflicts. In the case of bananas, the primary motivation was the safe use of pesticides for both workers and consumers, and for cocoa, the need to improve labor rights and conditions in small and medium growers in West Africa provided the initial stimulus. Regardless of the main drivers, the major standards used in each case have specific criteria to ensure that production comes from farms that have not engaged in clearing of primary forests after an agreed cut-off year and that protect natural eco-systems (Table 4). The requirements on clearing secondary forestland are more flexible, especially if land is titled or held in customary tenure. Definitions of forests in terms of high carbon stocks and high conservation value are being continually refined to better enforce standards on "zero deforestation". The Rainforest Alliance standard used in the banana industry has also moved toward landscape approaches that require that farms set aside land for conservation and to connect natural areas (Table 4).

Table 4. Comparison of certification of criteria for land use changes for the most important certifying schemes for cocoa, palm oil and bananas.

\begin{tabular}{|c|c|c|c|}
\hline $\begin{array}{l}\text { Certification System } \\
\text { \& Land Use Criteria }\end{array}$ & Cocoa & Palm Oil & Bananas \\
\hline $\begin{array}{l}\text { Main certification } \\
\text { system }\end{array}$ & UTZ & RSPO & Rainforest Alliance \\
\hline $\begin{array}{l}\text { Forests/Natural } \\
\text { ecosystems }\end{array}$ & $\begin{array}{l}\text { No conversion of primary } \\
\text { forests after } 2008 \\
\text { No deforestation or } \\
\text { degradation of other forests } \\
\text { unless clear rights and } \\
\text { government permits } \\
\text { (if needed) }\end{array}$ & $\begin{array}{l}\text { No conversion of primary } \\
\text { forests after } 2005 \\
\text { No planting on peat land } \\
\text { High conservation value } \\
\text { assessment to identify and } \\
\text { maintain biodiverse areas } \\
\text { Plans to minimize GHG } \\
\text { emissions Bans on fire }\end{array}$ & $\begin{array}{l}\text { No deforestation of natural } \\
\text { ecosystems since } 2005 \\
\text { Mitigation of any } \\
\text { degradation from } 1999-2005 \\
\text { At least } 30 \% \text { land on the } \\
\text { farm placed under } \\
\text { conservation Ecosystem } \\
\text { connectivity assured }\end{array}$ \\
\hline Land rights & $\begin{array}{l}\text { Demonstrate no significant } \\
\text { conflicts } \\
\text { Process to address } \\
\text { unresolved conflicts } \\
\text { Compensation for } \\
\text { infringed land rights }\end{array}$ & $\begin{array}{l}\text { Legitimate title and rights } \\
\text { not contested. } \\
\text { Participatory mapping to } \\
\text { show recognized users } \\
\text { Free prior and informed } \\
\text { consent of previous users } \\
\text { Fair compensation to } \\
\text { previous users } \\
\text { Social impact assessment on } \\
\text { livelihoods and subsistence } \\
\text { Open and transparent means } \\
\text { to communicate with local } \\
\text { communities Grievance } \\
\text { procedures to deal } \\
\text { with conflicts }\end{array}$ & $\begin{array}{l}\text { Official land title, or consent } \\
\text { of community and absence } \\
\text { of disputes Respect of areas } \\
\text { and activities important to } \\
\text { the community }\end{array}$ \\
\hline
\end{tabular}


Table 4. Cont.

\begin{tabular}{l|lll}
\hline $\begin{array}{l}\text { Main Certification } \\
\text { System and Land Use } \\
\text { Criteria }\end{array}$ & \multicolumn{1}{|c}{ Cocoa } & \multicolumn{1}{c}{ Palm Oil } & Bananas \\
\hline & $\begin{array}{l}\text { Group certification } \\
\text { possible Separate } \\
\text { sriteria for } \\
\text { smallholders }\end{array}$ & $\begin{array}{l}\text { Group certification possible } \\
\text { Separate criteria for smallholders }\end{array}$ & $\begin{array}{l}\text { Group certification } \\
\text { possible }\end{array}$ \\
\hline
\end{tabular}

Sources: Cocoa [60,61]; Oil palm [62,63]; Bananas-[64,65].

The standards on land rights exhibit much more heterogeneity and private companies and civil society are still searching for appropriate principles and criteria [66,67]. Current voluntary standards usually include the need to demonstrate rights to use of the land; and if official documents that ensure such rights are not available, growers must demonstrate the absence of disputes over land rights or the consent of local communities for the proposed land use, as well as respect for the ILO 169 Convention on the rights of indigenous and tribal peoples [60-62]. Standards on land rights are much more demanding for RSPO that mostly certifies plantations compared to UTZ and Rainforest Alliance that certify small and medium size banana and cocoa producers. RSPO, for example, includes specific clauses on participatory mapping to identify existing land users and free prior and informed consent and fair compensation to existing users to convert land to plantations (Table 4). Current certification standards for bananas and especially cocoa may overlook potential land conflicts associated with smallholder expansion, such as has recently occurred for cocoa in Côte d'Ivoire.

In all cases, a major challenge is to certify smallholders, since certification costs decline sharply per unit of output due to the fixed nature of many certification costs per farm [68]. RSPO and UTZ have special provisions for smallholders in efforts to reduce costs (Table 4). Costs can also be reduced where well-organized smallholders can receive group certification (all three systems) or where partnerships with company plantations (oil palm) facilitate formation of cooperatives and access to technical advice on certification.

Private standards, whether through industry roundtables or third party systems, are voluntary and this has major implications for their effectiveness. The first companies to become certified are often the ones that are leading industry efforts to improve sustainability so that the marginal gain from certification may be small, unless certification covers a large share of the industry [7]. Our first hand experiences with oil palm companies would bear this out.

Despite the multi-stakeholder nature of most private certification systems, they have been criticized for unequal power relations between companies and other actors, such as workers and smallholders, in the same way that state-led efforts to regulate land use changes have often been coerced by powerful private sector interests $[6,69]$. There may be some justification for this criticism but standards such as RSPO provide "discursive power and leverage to NGOs and social movements" that has been absent in many state-led schemes [70]. In general, the private standards are much more transparent and consultative than the state-based approaches and all are undergoing periodic revisions that tighten the codes [71,72]. 
Even if private standards are designed with wide stakeholder buy in and implemented through credible third party certification, it is unlikely that they can substitute for fair and transparent land institutions and regulations in an environment of weak governance of land and forest resources [7,70]. Indeed, there may be fundamental contradictions between private standards and state regulations such as when state terms on land concessions require planting the entire area in the concessions while private standards may require maintenance of areas of high conservation value or natural corridors along major streams [73].

One way to overcome these weaknesses of voluntary standards is to make the standards compulsory either on the demand side or the supply side. The EU's Renewable Energy Directive, for example, requires that biofuels comply with specific guidelines on deforestation and greenhouse gas savings. However, the guidelines do not include requirements on social standards with respect to land rights so that use of palm oil for biodiesel could comply with EU standards despite possible negative impacts on local land users [74]. On the supply side, Indonesia has introduced compulsory certification of oil palm plantations under its new Indonesian Sustainable Palm Oil (ISPO) regulations that has many criteria in common with the RSPO standards. Although the ISPO certification requires third party verification, it is doubtful that state involvement in standard setting will achieve credible standards given the record of poor governance of land and forest resources in Indonesia.

\subsection{Role of Global Actors}

Global actors have played a major role in setting standards for land use changes and land rights. Even within a colonial empire, there was often a sharp divergence of views between the metropolitan power and the local colonial government. For example, in French Indo-China rampant speculation on concession eventually led to a 1927 French government commission of enquiry that suspended land concessions followed by legislation of metropolitan powers of surveillance over all French colonies on matters of land concessions, although enforcement was weak. Historically too and in the modern era as we have just seen, multinational companies have been important actors in introducing private industry standards and certification. However, multinational companies have been in return responding to pressures from their financiers and consumers, and above all from civil society.

Civil society had sometimes been effective in promoting land rights of indigenous populations even during the first period of globalization. The UK-based Aborigines Protection Society had a long history of agitation for land rights in areas of European settlement in temperate areas but only occasionally took up the cause of land rights in tropical countries [75]. One example was the successful investigation and support of local communities against the extension of the forest reserve into areas used for shifting agriculture in what is now Sabah, Malaysia, during the period 1914-1919 [76].

In the modern era, civil society has often been effective in pressuring governments to reform land laws and improve land and forest governance, and companies to raise sustainability standards. Rapid expansion of crops such as oil palm is occurring under the spotlight of this global environmental movement that is pressuring the countries and companies involved in their production to act to reduce deforestation. The industry roundtables such as RSPO were initiated through a partnership between a leading NGO, the World Wildlife Fund, and industry. Commitments on zero deforestation such as that 
recently agreed for oil palm was brokered through pressure on major global traders in palm oil. Civil society has also raised global awareness of "land grabs" associated with the recent commodity boom as we have seen for rubber and oil palm.

Global science has also played an important role in designing institutions to manage land and forest resources, albeit sometimes with faulty science that was to the detriment of existing land users. Periodic Empire Forest Congresses from 1920 were important in standardizing the scientific forestry approach at the global level within the British Empire [53,77] and there were equivalent conferences across Europe. These congresses also provided the fora for scientific condemnation of shifting agriculture that re-enforced state policies to discourage the practice [53]. Since 1980, the science of biodiversity and climate change has played a critical role in highlighting the global public goods provided by tropical forests and mobilizing civil society around the world in what Grainger [77] terms "environmental globalization".

Science and civil society have also been influential in formulating the inter-governmental agreements and conventions relating to land and forest governance. Although land for tropical commodities in the first wave of globalization resulted in considerable loss of forests, this was largely ignored at the global scale; even as we have seen, land use transformations were often resisted by local resource users. During the current period of globalization, the mobilization of expanding scientific knowledge by a burgeoning civil society has greatly increased awareness of the value of global ecosystem services provided by forests and has resulted in a number of intergovernmental agreements. The value of the ecosystem services provided by tropical forests were addressed by the 1992 Earth Summit, the United Nations Conference on Environment and Development in Rio de Janeiro, resulting in two conventions, the Convention on Biodiversity in 1993 and the Framework Convention on Climate Change in 1994 with the latter giving rise to the UN-led mechanism for Reducing Emissions from Deforestation and Forest Degradation (REDD) in 2010. Although they created a surge in activity by multilateral institutions, NGOs and national governments to reduce deforestation [78] their overall impact was initially limited [7,79]. In part, the new agreements were seen in some developing countries as a form of neo-imperialism from northern environmental advocates, leading to weakening of agreements and resistance to their enforcement [9,77]. The two conventions did not set specific targets on deforestation (although a zero deforestation target by 2030 is now under discussion for a new round of sustainable development goals) nor did they provide a mechanism to slow deforestation until the advent of REDD. Although REDD provides positive incentives to conserve forests, its success depends on deepening of carbon markets and it is not clear if it will succeed in situations of poor forest governance or high commodity prices [80].

There has been no international organization charged with protecting claims to land rights until recently, and no international agreements or conventions protecting customary land rights. This contrasts with labor standards where the International Labor Organization (ILO) was established in 1919 and was mounting inspections of labor conditions on plantations by 1929 (See SI). Not until 1979 did an international conference attempted to establish norms for land rights and tenure but it was thwarted by Cold War politics [66]. Interestingly it seems that it was the ILO again that in 1989 led the first international convention that included explicit attention to land rights of indigenous groups, eventually resulting in a UN Declaration on the Rights of Indigenous Peoples in 2007. Land rights more generally were only addressed in 2012 in FAO's Voluntary Guidelines on the Responsible 
Governance of Tenure of Land, Fisheries and Forests in the Context of National Food Security, approved by the Committee on Food Security in 2012. A related set of voluntary guidelines on Principles for Responsible Agricultural Investment in Agriculture and Food Systems that includes specific clauses on land rights were also recently been agreed by the inter-governmental body, the Committee on Food Security in 2014 [81]. Discussions are also underway to include specific global land indicators or targets for land tenure security as part of the ongoing UN-led discussions of a new set of sustainable development goals for 2030 .

In short, the process of setting inter-governmental standards related to land resources started late in the game and progress has been slow. The fact that land and forest resources were regarded as sovereign to the countries themselves and the lack of recognition of global public goods associated with forests explain the long delay in global action on land issues. Still, the relatively short history of global action has greatly increased awareness and pressure on countries to conserve forest resources and protect land rights of local communities. In some cases, such as in the banana areas of Costa Rica, local actors influenced by the global environmental movement have led major changes in forest policy as well as in the will and capacity of the state to enforce the policy, resulting in a sharp decline in deforestation [55]. Even where the state has been reluctant to respond to international pressure, the international framework provided by conventions such as the UN Declaration on Rights of Indigenous Peoples has emboldened local communities to contest appropriation of forestlands for concessions in the courts, with some successes. For example, the Dayak peoples have successful contested infringement of customary tenure by oil palm companies in Sarawak, Malaysia [82,83].

\subsection{Importance of Commodity Characteristics}

Specific attributes of the commodities and their value chains have also been important in determining the outcomes related to land use changes and land rights. On the production side, smallholder systems are generally more favorable to social justice and land rights. However, particular attributes of some commodities, such as the need to process oil palm quickly after harvest in large mills or the need to bulk and ship fresh bananas, have favored vertical integration to enhance coordination of harvesting and post-harvest operations (Table 1). Large holdings in banana and palm oil original expansion favored large land-use changes and conflicts over land rights. These are not insurmountable problems as we have seen with the rise of small and medium sized oil palm and banana producers serving export markets.

Likewise, smallholder systems have sometimes preserved more of the natural ecosystem functions of tropical forests where such crops are amenable to production in bio-diverse agroforestry systems that provide more diverse livelihoods to growers. Cocoa, for example, was traditionally produced in agroforestry systems although its importance has declined over time [24,84,85]. Likewise, most smallholder rubber until recently was produced in agro-forestry systems that are estimated to conserve as much as $60 \%-80 \%$ of the biodiversity of natural forests $[27,86]$

Commodity attributes also matter on the consumer side as well. The negligible progress on certification of rubber, a commodity that is used largely as an industrial input, effectively dilutes consumer awareness of social and environmental standards in the rubber value chain. Bananas on the other hand are a commodity that is directly consumed without processing, and it is not surprising that 
the banana industry was among the frontrunners in adopting strict sustainability standards. Likewise, cocoa is a differentiated commodity used in many high value foods that demand certification.

The "sustainability premium" of course depends on consumers' willingness to pay and currently this demand is largely based on consumers in high-income countries. In all commodities, low and middle income countries make up a growing share of the market so creating a demand for certified products in these countries is critical to future growth of private standards (Table 5). This is especially so for palm oil, where certified palm oil is already approaching the share of rich countries in world palm oil markets $(20 \%)$ and the premium on certified palm oil is very low (less than $1 \%$ ).

Table 5. Extent of certification for cocoa, palm oil and bananas, 2014.

\begin{tabular}{lcccc}
\hline $\begin{array}{l}\text { Main certification } \\
\text { figures (2014) }\end{array}$ & Rubber & Cocoa & Palm Oil & Bananas \\
\hline \% Certified & & & & \\
- Production & Negligible & 17 & 17 & 18 \\
- Sales & & 7 & 8 & 14 \\
$\%$ Price premium & & 8 & $0.3-2.5$ & NA \\
\hline
\end{tabular}

Source: $[64,87]$.

\section{Conclusions}

Globalization and commodity exports have a long history in affecting land use changes and land rights on the tropical forest frontier. States have exercised sovereign rights over land and forest resources and the outcomes for deforestation and land rights of existing users have been quite varied depending on local institutional contexts and political economy. For the four commodities we have reviewed, global and local actors have sometimes successfully applied pressure to conserve forests and respect local land rights, but more often land policies and institutions have supported conversion of forests and restriction on the rights of local communities, especially with respect to shifting agriculture and access to forest resources. These policies have followed the dominant ethos of the time that place low values on tropical forests but have also responded to powerful interest groups of plantation companies.

In the current period of globalization, land use changes associated with tropical commodities have accelerated. This has coincided with increasing knowledge of the value of global public goods provided by forests and with greater concerns about equitable outcomes from agribusiness investments and trade in tropical commodities. Land issues are now at center stage in the global discourse on tropical commodities although many countries and companies have resisted international pressure to improve social and environmental outcomes. Land rights in particular have only moved to center stage in the past few years and international guidelines and agreements are very much a work in progress.

Given a widespread failure of states to curb deforestation and protect land rights, three of the industries reviewed are emphasizing private voluntary standards to certify social and environmental sustainability of their products. This is an important step but expectations that they will address concerns about the social and environmental sustainability of tropical commodities are too high given their voluntary nature, demand constraints, and the challenge of certifying smallholders. It is doubtful that private standards can more than partially compensate for wider weaknesses in state land and forest 
governance and institutions. Without minimum standards agreed to by international conventions on land tenure and rights and forest conservation, we are likely to see a continuation of a "race to the bottom" and "leakages" in places where governments set liberal policies on accessing land to attract investors, frequently at the expense of local farmers and forest dwellers, and their forest resources.

\section{Acknowledgments}

We appreciate the valuable comments of two peer reviewers.

\section{Author Contributions}

The authors provided equal contributions.

\section{Conflicts of Interest}

The authors declare no conflict of interest.

\section{References}

1. Mintz, S.W. Sweetness and Power: The Place of Sugar in Modern History; Viking: New York, NY, USA, 1985.

2. Beckford, G.L. Persistent Poverty: Underdevelopment in Plantation Economies of the Third World; Oxford University Press: New York, NY, USA, 1972.

3. Tucker, R.P. Insatiable Appetite: The United States and the Ecological Degradation of the Tropical World; University of California Press: Berkeley, CA, USA, 2000.

4. Deininger, K.W.; Derek, B. Rising Global Interest in Farmland: Can It Yield Sustainable and Equitable Benefits? World Bank: Washington, DC, USA, 2011.

5. Cotula, L. The Great African Land Grab? Agricultural Investments and the Global Food System; Zed Books: London, UK, 2013.

6. Fortin, E.; Richardson, B. Certification schemes and the governance of land: Enforcing standards or enabling scrutiny? Globalizations 2013, 10, 141-159.

7. Lambin, E.F.; Meyfroidt, P. Global Land Use Change, Economic Globalization, and the Looming Land Scarcity. Proc. Natl. Acad. Sci. USA 2011, 108, 3465-3472.

8. Topik, S.C.; Wells, A. Global Markets Transformed: 1870-1945; The Belknap Press of Harvard University Press: Cambridge, MA, USA; London, UK, 2014.

9. Williams, M. Deforesting the Earth: From Prehistory to Global Crisis, an Abridgement; University of Chicago Press: Chicago, IL, USA, 2003.

10. Meyfroidt, P.; Carlson, K.M.; Fagan, M.E.; Gutiérrez-Vélez, V.H.; Macedo, M.N.; Curran, L.M.; Robiglio, V. Multiple pathways of commodity crop expansion in tropical forest landscapes. Environ. Res. Lett. 2014, 9, doi:10.1088/1748-9326/9/7/074012.

11. Newton, P.; Agrawal, A.; Wollenberg, L. Enhancing the sustainability of commodity supply chains in tropical forest and agricultural landscapes. Glob. Environ. Chang. 2013, 23, 1761-1772.

12. FAO. FAOSTAT. Retrieved 10/03/2012, from Food and Agriculture Organization of the United Nations FAOSTAT; FAO: Rome, Italy, 2012. 
13. Rudorff, B.F.T.; Adami, M.; Risso, J.; de Aguiar, D.A.; Pires, B.; Amaral, D.; Fabiani, L.; Cecarelli, I. Remote sensing images to detect soy plantations in the Amazon biome-The soy moratorium initiative. Sustainability 2012, 4, 1074-1088.

14. Pacheco, P.; Aguilar-Støen, M.; Börner, J.; Etter, A.; Putzel, L.; del Carmen Vera Diaz, M. Landscape transformation in tropical Latin America: Assessing trends and policy Implications for REDD+. Forests 2010, 2, 1-29.

15. Wunder, S. Ecuador Goes Bananas: Incremental Technological Change and Forest Loss. In Agricultural Technologies and Tropical Deforestation; Arild, A., Kaimovitz, D., Eds.; CABI International: Wallingford, UK, 2001.

16. Johns, N.D. Conservation in Brazil's chocolate forest: The unlikely persistence of the traditional cocoa agroecosystem. Environ. Manag. 1999, 23, 31-47.

17. Ruf, F.; Schroth, G.; Doffangui, K. Climate change, cocoa migrations and deforestation in West Africa: What does the past tell us about the future? Sustain. Sci. 2015, 10, 101-111.

18. Beinart, W.; Hughes, L. Environment and Empire; Oxford University Press: Oxford, UK, 2007.

19. Rudel, T.K.; Defries, R.; Asner, G.P.; Laurance, W.F. Changing drivers of deforestation and new opportunities for conservation. Conserv. Biol. 2009, 23, 1396-1405.

20. DeFries, R.S.; Rudel, T.; Uriarte, M.; Hansen, M. Deforestation driven by urban population growth and agricultural trade in the twenty-first century. Nat. Geosci. 2010, 3, 178-181.

21. Lambin, E.F.; Meyfroidt, P.; Rueda, X.; Blackman, A.; Börner, J.; Cerutti, P.O.; Dietschh, T.; Jungmanni, L.; Lamarquea, P.; Listerj, J.; et al. Effectiveness and synergies of policy instruments for land use governance in tropical regions. Glob. Environ. Chang. 2014, 28, 129-140.

22. Gunarso, P.; Manjela, E.H., Fahmuddin, A.; Killen, T.J. Oil Palm and Land Use Change in Indonesia, Malaysia and Papua New Guinea. Report from the Technical Panels of the 2nd Greenhouse Gas Working Group; RSPO: Kuala Lumpur, Malaysia, 2013.

23. Ziegler, A.D.; Fox, J.M.; Xu, J. The rubber juggernaut. Science 2009, 324, 1024-1025.

24. Clough, Y.; Faust, H.; Tscharntke, T. Cacao boom and bust: Sustainability of agroforests and opportunities for biodiversity conservation. Conserv. Lett. 2009, 2, 197-205.

25. Ruf, F.; Ehret, P.; Yoddang, C.T. Smallholder cocoa in Indonesia: Why a cocoa boom in Sulawesi? In Cocoa Pioneer fronts since 1800: The Role of Smallholders, Planters, and Merchants; Clarence-Smith, W.G., Ed.; Mac Millan: London, UK, 1996.

26. Byerlee, D. The fall and rise again of plantations in tropical Asia: History repeated? Land 2013, 3, 574-597.

27. Dove, M. The Banana Tree at the Gate: A History of Marginal Peoples and Global Markets in Borneo; Yale University Press: New Haven, CT, USA, 2011.

28. Wickizer, V.D. The Plantation System in the Development of Tropical Economies. J. Farm Econ. 1958, 40, 63-77.

29. Greaves, I.C. Modern Production among Backward Peoples; G. Allen \& Unwin: London, UK, 1935.

30. Hodge, J.M. Triumph of the Expert: Agrarian Doctrines of Development and the Legacies of British Colonialism; Ohio University Press: Athens, OH, USA, 2007.

31. Drabble, J.H. Rubber in Malaya, 1876-1922; the Genesis of the Industry; Oxford University Press: Kuala Lumpur, Malaysia, 1973. 
32. Banner, S. Possessing the Pacific: Land, Settlers, and Indigenous People from Australia to Alaska; Harvard University Press: Cambridge, MA, USA, 2007.

33. Banerjee, A.; Lakshmi, I. History, Institutions and Economic Performance: The Legacy of Colonial Land Tenure Systems in India: Social Science Research Network. Available online: http://papers.ssrn.com/sol3/papers.cfm?abstract_id=321721 (accessed on 12 April 2015).

34. Baden-Powell, B.H. Forest Law: A Course of Lectures on the Principles of Civil and Criminal Law and on the Law of the Forest; Agnew: London, UK; Bradbury, CA, USA, 1893.

35. Guha, R. Environmentalism: A Global History; Longman: New York, NY, USA, 2000.

36. Courtenay, P.P. The Plantation in Malaysian Economic Development. J. Southeast Asian Stud. 1981, 12, 329-348.

37. Wily, L.A. "The Law is to Blame": The Vulnerable Status of Common Property Rights in Sub-Saharan Africa. Dev. Chang. 2011, 42, 733-757.

38. Hall, D. Land grabs, land control, and Southeast Asian crop booms. J. Peasant Stud. 2011, 38, 837-857.

39. Woods, D. The Tragedy of the Cocoa Pod: Rent-Seeking, Land and Ethnic Conflict in Ivory Coast. J. Mod. Afr. Stud. 2003, 41, 641-655.

40. Colchester, M.; Norman, J.; Sophie, C. Conflict or Consent? Oil Palm Expansion and Community Rights. In Proceedings of the Annual World Bank Conference on Land and Poverty, the World Bank-Washington, DC, USA, 8-11 April 2013.

41. Arezki, R.; Deininger, K.; Selod, H. What Drives the Global "Land Rush"? World Bank Econ. Rev. 2013, doi:10.1093/wber/lht034.

42. Feder, G.; Onchan, T.; Chalamwong, Y.; Hongladarom, C. Land Policies and Farm Productivity in Thailand; Published for the World Bank; Johns Hopkins University Press: Baltimore, MD, USA, 1988.

43. Gourou, P. The Tropical World: Its Social and Economic Conditions and Its Future Status; Longmans, Green and Co.: London, UK, 1953.

44. Little, I.M.D.; Tipping, D.G. A Social Cost Benefit Analysis of the Kulai Oil Palm Estate: West Malaysia; Development Centre of the Organisation for Economic Cooperation and Development: Paris, France, 1972.

45. Murray, M.J. The Development of Capitalism in Colonial Indochina (1870-1940); University of California Press: Berkeley, CA, USA, 1980.

46. Booth, A. Colonial Legacies Economic and Social Development in East and Southeast Asia; University of Hawaii Press: Honolulu, HI, USA, 2007.

47. Bucheli, M. Multinational Corporations, Totalitarian Regimes and Economic Nationalism: United Fruit Company in Central America, 1899-1975; Business History; Routledge: London, UK, 2008; volume 50.

48. Bucheli, M. Bananas and Business: The United Fruit Company in Colombia, 1899-2000; New York University Press: New York, NY, USA, 2004.

49. Striffler, S. In the Shadows of State and Capital: The United Fruit Company, Popular Struggle, and Agrarian Restructuring in Ecuador, 1900-1995; Duke University Press: Durham, NC, USA, 2002. 
50. Cramb, R.; Curry, G.N. Oil palm and rural livelihoods in the Asia-Pacific region: An overview. Asia Pac. Viewp. 2012, 53, 223-239.

51. Troup, R.S.; Swynnerton, C.F.M. Colonial Forest Administration; Oxford University Press: London, UK, 1940.

52. Peluso, N.L.; Vandergeest, P. Genealogies of the political forest and customary rights in Indonesia, Malaysia, and Thailand. J. Asian Stud. 2001, 60, 761-812.

53. Rajan, S.R. Modernizing Nature: Forestry and Imperial Eco-Development 1800-1950; Clarendon Press: Oxford, UK, 2006.

54. Von Hellermann, P.; Usuanlele, U. The owner of the land: The Benin Obas and colonial forest reservation in the Benin Division, Southern Nigeria. J. Afr. Hist. 2009, 50, 223-246.

55. Fagan, M.E.; DeFries, R.S.; Sesnie, S.E.; Arroyo, J.P.; Walker, W.; Soto, C.; Chazdon, R.L.; Sanchun, A. Land cover dynamics following a deforestation ban in northern Costa Rica. Environ. Res. Lett. 2013, 8, 1-9.

56. Robinson, B.E.; Holland, M.B.; Naughton-Treves, L. Does secure land tenure save forests? A meta-analysis of the relationship between land tenure and tropical deforestation. Glob. Environ. Chang. 2014, 29, 281-293.

57. Higgs, C. Chocolate Islands: Cocoa, Slavery, and Colonial Africa; Ohio University Press: Athens, OH, USA, 2012.

58. Martin, S.M. The UP Saga; NIAS Press: Copenhagen, Denmark, 2004.

59. Global Rubber Markets. Available online: http://globalrubbermarkets.com/17884/irsg-launchessustainable-natural-rubber-initiative.html (accessed on 12 Arpil 2015).

60. UTZ. Utz Certified Good Inside_-Standards Map. Available online: file://C:/Users/AFH\%20 Design\%20Fellow/Downloads/UTZ_EN.pdf (accessed on 12 April 2015).

61. UTZ, 2014. Standards and Certification. Available online: https://www.utzcertified.org/ aboututzcertified/standardcertification (accessed on 12 April 2015).

62. Roundtable on Sustainable Palm Oil (RSPO), RSPO Principles and Criteria for the Production of Sustainable Palm Oil. Available online: http://www.rspo.org/en/document_principle and_criteria_certification (accessed on 30 June 2014).

63. Roundtable on Sustainable Palm Oil (RSPO). An International Multilevel Stakeholder Initiative Transforming Markets to Make Sustainable Palm Oil the Norm; PowerPoint Presentation, Roundtable on Sustainable Palm Oil: Kuala Lumpur, Malaysia, 2014.

64. Rainforest Alliance-Sustainable Agricultural Network. Our Standards. Available online: http://san.ag/web/our-standard/ (accessed on 12 April 2015).

65. SAN. Sustainable Agriculture Standard; Sustainable Agriculture Network: San José, Costa Rica, 2010.

66. Margulis, M.E.; Porter, T. Governing the global land grab: Multipolarity, ideas, and complexity in transnational governance. Globalizations 2013, 10, 65-86.

67. Voget-Kleschin, L.; Stephan, S. The Potential of Standards and Codes of Conduct in Governing Large-Scale Land Acquisition in Developing Countries towards Sustainability. J. Agric. Environ. Ethics 2013, 26, 1157-1179.

68. Beall, E. Smallholders in Global Bioenergy Value Chains and Certification: Evidence from Three Case Studies; FAO: Rome, Italy, 2012. 
69. Marin-Burgos, V.; Clancy, J.S.; Lovett, J.C. Contesting legitimacy of voluntary sustainability certification schemes: Valuation languages and power asymmetries in the Roundtable on Sustainable Palm Oil in Colombia. Ecol. Econ. 2014, doi:10.1016/j.ecolecon.2014.04.011.

70. McCarthy, J.F. Certifying in Contested Spaces: Private regulation in Indonesian forestry and palm oil. Third World Q. 2012, 33, 1871-1888.

71. Pichler, M. "People, Planet \& Profit": Consumer-Oriented Hegemony and Power Relations in Palm Oil and Agrofuel Certification. J. Environ. Dev. 2013, 22, 370-390.

72. Nesadurai, H.E. Food security, the palm oil-land conflict nexus, and sustainability: A governance role for a private multi-stakeholder regime like the RSPO? Pac. Rev. 2013, 26, 505-529.

73. Hospes, O.; Kentin, A. Tensions between Global Scale and National Scale Governance: The Strategic Use of Scale Frames to Promote Sustainable Palm Oil Production in Indonesia. In Scale-Sensitive Governance of the Environment; Padt, F., Opdam, P., Polman, N., Termeer, C., Eds.; John Wiley \& Sons: Hoboken, NJ, USA, 2014.

74. German, L.; Schoneveld, G. A review of social sustainability considerations among EU-approved voluntary schemes for biofuels, with implications for rural livelihoods. Energy Policy 2012, 51, $765-778$.

75. Heartfield, J. Aborigines' Protection Society; Humanitarian Imperialism in Australia, New Zealand, Fiji, Canada, South Africa, and the Congo, 1837-1909; Columbia University Press: New York, NY, USA, 2011.

76. Cleary, M.C. Plantation Agriculture and the Formulation of Native Land Rights in British North Borneo c. 1880-1930. Geogr. J. 1992, 158, 170-181.

77. Grainger, A. Environmental globalization and tropical forests. Globalizations 2005, 2, 335-348.

78. Freer-Smith, P.; Carnus, J.M. The Sustainable Management and Protection of Forests: Analysis of the Current Position Globally. Ambio 2008, 37, 254-262.

79. Fischer, J.; Brosi, B.; Daily, G.C.; Ehrlich, P.R.; Goldman, R.; Goldstein, J.; Lindenmayer, D.B.; Manning, A.D.; Mooney, H.A.; Pejchar, L.; et al. Should Agricultural Policies Encourage Land Sparing or Wildlife-Friendly Farming? Front. Ecol. Environ. 2008, 6, 380-385.

80. Sunderlin, W.D.; Larson, A.M.; Duchelle, A.E.; Resosudarmo, I.A.P.; Huynh, T.B.; Awono, A.; Dokken, T. How are REDD+ proponents addressing tenure problems? Evidence from Brazil, Cameroon, Tanzania, Indonesia, and Vietnam. World Dev. 2014, 55, 37-52.

81. FAO. Principles for Responsible Agricultural Investment that Respect Rights, Livelihoods and Resources (PRAI). Available online: http:/www.fao.org/economic/est/issues/investments/ prai/en (accessed on 1 September 2014).

82. Cramb, R.; Sujang, P.S. "Shifting ground": Renegotiating land rights and rural livelihoods in Sarawak, Malaysia. Asia Pac. Viewp. 2011, 52, 136-147.

83. Colchester, M.; Pang, W.A.; Chuo, W.M.; Jalong, T. Land is Life: Land Rights and Oil Palm Development in Sarawak. Forest Peoples Program. Available online: http://www.forestpeoples.org/sites/fpp/files/publication/2010/08/sarawaklandislifenov07eng.pdf (accessed on 12 April 2015).

84. Ruf, F.O. The Myth of Complex Cocoa Agroforests: The Case of Ghana. Hum. Ecol. Interdiscip. J. 2011, 39, 373-388. 
85. Rice, R.A.; Greenberg, R. Cacao Cultivation and the Conservation of Biological Diversity. Ambio 2000, 29, 167-173.

86. Hicks, C.; Voladeth, S.; Shi, W.; Guifeng, Z.; Lei, S.; Tu, P.Q.; Kalina, M. Rubber Investments and Market Linkages in Lao PDR: Approaches for Sustainability? Sustainable Mekong Research Network: Bangkok, Thailand, 2009.

87. Potts, J.; Lynch, M.; Wilkings, A.; Huppé, G.; Cunningham, M.; Voora. V. The State of Sustainability Initiatives Review 2014: Standards and the Green Economy; International Institute for Sustainable Development, Manitoba and the International Institute for Environment and Development: London, UK, 2014.

(C) 2015 by the authors; licensee MDPI, Basel, Switzerland. This article is an open access article distributed under the terms and conditions of the Creative Commons Attribution license (http://creativecommons.org/licenses/by/4.0/). 